\title{
Safe drinking water still a dream in rural areas of South Africa. Case Study: The Eastern Cape Province
}

\author{
MNB Momba ${ }^{1 *}, \mathrm{Z}$ Tyafa $^{2}$, N Makala ${ }^{2}$, BM Brouckaert $^{3}$ and CL Obi ${ }^{4}$ \\ ${ }^{1}$ Tshwane University of Technology, Water Care Department, P/Bag x680, Pretoria 0002, South Africa \\ 2 Department of Microbiology and Biochemistry, University of Fort Hare, P/Bag X1314, Alice 5700, South Africa \\ ${ }^{3}$ Pollution Research Group, School of Chemical Engineering, University of Kwazulu-Natal, Durban 4041, South Africa \\ ${ }^{4}$ College of Agriculture and Environmental Sciences, School of Agriculture and Life Sciences, University of South Africa, \\ Pretoria, South Africa
}

\begin{abstract}
From October to November 2004, and from July to September 2005, a survey of 55 plants was conducted in five District Municipalities (Cacadu, Chris Hani, Amathola, Ukhahlamba and O.R. Tambo) of the Eastern Cape Province, with the aim of examining the disinfection practices used in small rural systems of the Eastern Cape and their effect on the quality of drinking water they supply to the communities.

Eighty six percent of the visited plants were treating surface water while $7 \%$ were treating groundwater and another $7 \%$ were treating both ground- and surface water. The majority of plants surveyed employed some variation of conventional treatment (coagulation, flocculation, sedimentation, filtration, chlorination). Turbidity values in $55 \%$ of the plants were within the acceptable SABS limits while the other $45 \%$ showed high values.

Out of the 55 surveyed plants only $18 \%$ complied with the SABS recommended limits in terms of microbiological quality. The major factors that contributed to high bacterial numbers were high turbidity and inefficient chemical (coagulant and chlorine) dosing, which led to low chlorine residuals. It was also noted that although some plants had low bacterial numbers at the point of treatment, bacterial re-growth occurred in the distribution system, thereby compromising the quality of water at the point of use.

The worst technical problems encountered tended to be at the newly commissioned or upgraded plants where properly trained operators had yet to be appointed or where the existing staff lack proficiency in the use of the upgraded systems or why certain modifications to the treatment process were being made.

Operators were lacking in the required technical knowledge such as flow rate and chemical dosing to effectively execute their duties. Lack of communication between consultants, operators and municipal officials on technical issues relating to plant operation appeared to be a problem.

The results of this study gave conclusive evidence that rural water treatment plants are still failing to produce safe drinking water.
\end{abstract}

Keywords: safe drinking water, failure, Eastern Cape, rural areas

\section{Introduction}

Access to safe drinking water is a fundamental human need and therefore, a basic right. Contaminated water jeopardises both the physical and social health of all people and it is an affront to human dignity (WHO, 2003). The Water Decade has been preoccupied with construction and expansion of supplies and it is only in the latter part of the decade that more attention is being given to the investigation, protection and control of the installations, which supply drinking water Lloyd and Bartrams (1991).The fundamental responsibility of a public water supply is to provide safe drinking water that is adequate in quantity and acceptable quality to each consumer.

Prior to 1994, an estimated 30 to $40 \%$ of South Africa's population (approximately 14 to $18 \mathrm{~m}$. people) was without adequate water supply services. As of 2004, 10m. people have been supplied with drinking water. However, despite the significant improvements made by government in water services provision, some $5 \mathrm{~m}$. people are still obtaining water from rivers

This paper was originally presented at the 2006 Water Institute of South Africa (WISA) Biennial Conference, Durban, South Africa, 21-25 May 2006.

* To whom all correspondence should be addressed.

푱+2712 382-6365; fax:+2712 382-6233;

e-mail: mombamnb@.tut.ac.za and springs Kasrils (2004). While the South African government implemented many rural water supply schemes under the National Reconstruction and Development Programme, where rural water supply existed, drinking water is often of poor quality and considered unsafe.

Studies have shown that the majority of small water works in South Africa have difficulty in providing adequate treatment and disinfection with the result that consumers are at risk of waterborne diseases even from treated water supplies Mackintosh and Colvin (2002); Momba et al. (2002; 2003); Swartz (2000). The Eastern region of the Eastern Cape features various nodes where water resources combine with a well-developed system of purification plants and bulk water supply networks. These allow for provision of water services of a standard contrasts with that in the province's rural territories, where water treatment and supply facilities remain underdeveloped. Many rural settlements currently have only rudimentary water supply facilities or have access to potable water supply that falls below the minimum quality or quantity standards set by the government Beyl and Associates (2003/2004). Small communities face the greatest difficulty in supplying water of adequate quality and quantity because they have small customer bases and therefore often lack the revenues needed to hire experienced managers and to maintain and upgrade their water supply facilities. Inter- 


\begin{tabular}{|l|c|l|}
\hline \multicolumn{3}{|c|}{ List and locations of the water treatment plants surveyed } \\
\hline $\begin{array}{l}\text { Municipalities } \\
\text { surveyed }\end{array}$ & $\begin{array}{l}\text { Number } \\
\text { of plants }\end{array}$ & Locations of plants \\
\hline Cacadu District & 17 & $\begin{array}{l}\text { Graaf Reinett, Aberdeen, Willowmore, Pearston, Somerset East, Cookhouse, Joubertina, } \\
\text { Louterwater, Kareedouw, Hankey, Patensie, Humansdorp, Jeffrey's Bay, Port Alfred, } \\
\text { Bathurst, Seafield and Albany }\end{array}$ \\
\hline Amatole District & 11 & $\begin{array}{l}\text { Idutywa, Butterworth, Elliotdale, Komga, Carthcart, Cintsa, Kei Mouth, Morgan's Bay, } \\
\text { Hagahaga, Adelaide and Bedford }\end{array}$ \\
\hline Chris Hani District & 9 & $\begin{array}{l}\text { Queenstown, Cradock, Molteno, Sada, Cofimvaba, Dordrecht, Machubeni, Engcobo and All } \\
\text { Saint's }\end{array}$ \\
\hline O. R. Tambo District & 10 & $\begin{array}{l}\text { Umtata, Mqanduli, Ngqeleni, Mthatyana, Libode, Bulolo, Umzimvubu, Mt Ayliff, Mt Frere } \\
\text { and Tsolo }\end{array}$ \\
\hline Ukhahlamba District & 8 & Maclear, Sonwabile, Ugie, Lady Grey, Aliwal North, Burgersdorp, Barkley East and Elliot \\
\hline
\end{tabular}

ruptions in water service due to inadequate management as well as violations of drinking water standards are problems for some of these systems. Although the problems of supplying drinking water through individually operated small water systems have long been known, the number of small water systems continued to increase.

In this paper, we report the microbiological and physicochemical qualities of the small water supply systems in the Eastern Cape Province of South Africa, their compliance to the drinking water standards and the likely status of their quality management based on the visitations made to 55 small water treatment plants in the Amatole, Cacadu, Ukhahlamba, Chris Hani and OR Tambo District Municipality and literature review.

\section{Methodology}

\section{Water quality variables}

The water quality parameters used to measure the environmental health risk during this study were: the SABS (2001) and the South African Water Quality Guidelines (DWAF, 1996).

\section{Description of survey area}

Eastern Cape is the second poorest province in South Africa with restricted resources, forced settlement, lack of democratic control of development and poor education, and its population is largely non-urban, poor, and with an inadequate water-supply infrastructure (CSS, 1998; Mey, 1998) It is the second largest of the nine provinces in South Africa and comprises forty six Municipalities. The study was conducted in 55 plants located in Cacadu, Chris Hani, Amatole, Ukhahlamba and OR Tambo District Municipalities of the Eastern Cape Province of South Africa (Table 1).

\section{Assessment of operational status of the plants}

The general operational status of the plants visited were assessed with particular emphasis on the water abstraction source, treatment processes in place, and other non-technical issues related to the plants operations such as personnel and capacity building.

\section{Water quality analysis}

Plant managers and operators were interviewed to obtain information on the operation and maintenance of the plants and the various disinfection practices in each plant were surveyed. A mobile laboratory containing all necessary equipment (mem- brane filtration unit, a vacuum pump, kettles, small ovens, portable incubators, sterile Petri dishes containing selective cultural media, sterile membrane filters, $\mathrm{pH}$ meter, thermometer, turbidity meter, chlorine meter, conductivity meter, etc.) was used for on-site analysis of water quality. Raw water and treated water in the plants and at the point of end users (distribution system) were collected for physicochemical and microbiological analyses.

Samples for microbiological analysis were aseptically collected into sterile bottles (bottles for disinfected water samples contained $17.5 \mathrm{mg} / \ell$ sodium thiosulphate). Microbiological analysis was limited to total and faecal coliforms. The membrane filtration technique, chromocult coliform agar (Merck), M-Endo agar Les (BioLab) and M-FC agar (BioLab) were used for the enumeration of coliforms. Water samples were analysed for these micro-organisms using internationally accepted techniques and principles.

Water samples for the physicochemical analyses were collected in thoroughly cleaned non-sterile bottles. The chlorine residual, $\mathrm{pH}$, temperature and turbidity were measured using a multi-parameter ion specific meter (Hanna_BDH laboratory supplies), a thermometer and a microprocessor turbidity meter (HACH company, model 2100P) respectively. Conductivity was determined using a conductivity meter (CRISON CM35, Crison instrument).

The physicochemical and microbiological water quality parameters were then compared to the standards set by the SABS (2001) and DWAF Water Quality Guidelines for Domestic Use (DWAF, 1996).

\section{Identification of coliform isolates}

After counting bacterial colonies, plates were selected for identification of bacterial isolates. Bacterial colonies differing in size, shape and colour were randomly selected from the different plates and further isolated on MacConkey agar (Merck) by streak plate technique and incubated at $37^{\circ} \mathrm{C}$ for $24 \mathrm{~h}$. These isolates were further purified by the same method at least three times using nutrient agar (BioLab). Oxidase tests were then done on those colonies that were Gram negative. The API $20 \mathrm{E}$ kit was used for the oxidase-negative colonies and the strips were incubated at $35^{\circ} \mathrm{C}$ for $24 \mathrm{~h}$. The strips were then read and the final identification was done using API LAB PLUS computer software (BioMérieux).

\section{Statistical analysis}

The statistical analysis was done in two parts, namely exploratory and confirmatory analyses. Treatment means plots were 


\begin{tabular}{|c|c|c|c|c|c|c|c|c|c|c|c|}
\hline \multicolumn{12}{|c|}{$\begin{array}{l}\text { TABLE } 2 \\
\text { Some non- technical issues impacting on quality of water services delivery in small water treatment plants } \\
\text { in the Eastern Cape Province }\end{array}$} \\
\hline & \multicolumn{3}{|c|}{ Operators' qualification(\%) } & \multicolumn{3}{|c|}{ Experience (years) (\%) } & \multicolumn{3}{|c|}{ Salary (pm) (\%) (Rand) } & \multicolumn{2}{|c|}{ Training } \\
\hline & $<$ Std 8 & $\begin{array}{c}\text { Std } 8 \\
\text {-Matric }\end{array}$ & $\begin{array}{l}\text { Post } \\
\text { Matric }\end{array}$ & $<5$ & $5-10$ & $11+$ & $\begin{array}{c}1000-2 \\
000\end{array}$ & $\begin{array}{c}3000-4 \\
000\end{array}$ & $5000+$ & Yes & No \\
\hline Range & $\begin{array}{c}28.58- \\
62.5 \\
\end{array}$ & $\begin{array}{c}25.0- \\
38.1 \\
\end{array}$ & $\begin{array}{c}9.52- \\
35.7\end{array}$ & $\begin{array}{l}18.75- \\
34.78 \\
\end{array}$ & $\begin{array}{l}6.25- \\
38.46 \\
\end{array}$ & $\begin{array}{c}34.62- \\
62.5 \\
\end{array}$ & $\begin{array}{l}20.0- \\
66.66 \\
\end{array}$ & $\begin{array}{c}26.67- \\
75 \\
\end{array}$ & $\begin{array}{c}0- \\
16.67 \\
\end{array}$ & $\begin{array}{c}11.1- \\
52.94 \\
\end{array}$ & $\begin{array}{l}47.1- \\
88.9 \\
\end{array}$ \\
\hline $\begin{array}{l}\text { Mean } \\
\text { (SD) }\end{array}$ & $\begin{array}{l}49.2 \\
(13.1)\end{array}$ & $\begin{array}{l}32.3 \\
(6.1)\end{array}$ & $\begin{array}{c}18.3 \\
(10.2)\end{array}$ & $\begin{array}{l}27.1 \\
(6.3)\end{array}$ & $\begin{array}{c}25 \\
(12)\end{array}$ & $\begin{array}{c}48 \\
(11.3)\end{array}$ & $\begin{array}{c}36.8 \\
(19.4)\end{array}$ & $\begin{array}{c}54.4 \\
(20.8)\end{array}$ & $\begin{array}{c}8.8 \\
(7.1)\end{array}$ & $\begin{array}{c}35.4 \\
(15.9)\end{array}$ & $\begin{array}{l}64.6 \\
(15.9)\end{array}$ \\
\hline
\end{tabular}

used in the graphical exploratory analysis and tests of significance formed the confirmatory analysis. Pearson's correlation analysis was used for testing for the linear association between pairs of the variables chlorine, log total coliform counts and log faecal counts. A follow up linear regression analysis was used to determine the pattern of relationship between the coliform counts as responses and residual chlorine as the predictor. To test if residual chlorine and log coliform counts depended on municipality and sampling point as explanatory variable, a twoway analysis of variance was used. All tests were carried out at a $5 \%$ level of significance.

\section{Results and discussion}

\section{Summary of key issues identified from the survey}

Majority of the plants surveyed were owned by the district municipalities. However, some of the plants were either owned by Department of Water Affairs and Forestry (DWAF), Department of Health or by Water Board. Several supervisors/local officials commented that the centralisation of authority with the district municipalities created some difficulties for them as the district municipalities tended to respond too slowly to problems arising at plants, which are generally located at considerable distances from the district offices. The takeover of local municipalities by district municipalities appeared to have negatively impacted operators' wages in some cases.

We observed that the majority $(86 \%)$ of the visited plants were treating surface water while $7 \%$ of the plants were abstracting their water from groundwater sources and another $7 \%$ were abstracting water from both sources. Conventional water treatment processes such as coagulation, flocculation, sedimentation, filtration and chlorination are mostly in use, although one desalination plant was also visited. Few plants were still using alum and lime (21\%) for coagulation but most appear to be switching to some forms of polymeric coagulant (77\%) (such as Sudfloc, Ultrafloc, Ferrifloc, Primco, Profloc, M7005, Zeta floc, Polyfloc, $\mathrm{P} 101)$ and powdered activated carbon (2\%). Coagulant doses were adjusted manually, usually based on the appearance of the floc and sometimes on the taste of the water in case of alum. While chlorine (54\% chlorine gas, 33\% HTH and 9\% hypochlorite-liquid) remained the most common disinfectant used, $2 \%$ of the plants used ozone (as a post-disinfectant) and $2 \%$ of the plant used bromine. In all cases chlorine doses were manually set. Operators often reported that they increased chlorine doses when the raw water turbidity increased after heavy rains even if they were unable to measure the finished water turbidity or the chlorine residual. Where chlorine residuals were measured, supervisors often believed that a chlorine residual of $0.1 \mathrm{mg} / \ell$ in the finished water was adequate.

It was generally very difficult to find some of the data required in the surveys. This was primarily due to the lack of operation and maintenance manuals as well as the lack of standard operating procedures. Procurement of chemicals was reported to be a major problem, especially in the outlying areas. Maintenance of equipment often resulted in premature failure of equipment.

The worst technical problems encountered tended to be at newly commissioned (11\% of the plants surveyed) or upgraded (36.4\% of the plants surveyed) plants where properly trained operators had yet to be appointed or where the existing staff did not know how to use the upgraded systems or why certain modifications to the treatment process were being made. Operators were devoid of the required technical knowledge such as flow rate and chemical dosing to effectively execute their duties. Lack of communication between consultants, operators and municipal officials on technical issues relating to plant operation appeared to be a major problem in small rural water supplies in the Eastern Cape Province.

Table 2 summarises some non-technical issues impacted negatively on the quality of drinking water services delivery. While most of the operators have over 11 years of working experience at the plant, they are nevertheless poorly educated $(<$ Std 8 ), with only $18.3 \%$ having post-matric qualifications. The implications of these trends are enormous because they typify the shortcomings and potential dangers in the water delivery system due to lack of appropriate qualification and training. The in-service training component is exemplified by the fact that in all the small water treatment plants studied in the Eastern Cape Province, about 7 to $64 \%$ of the operators had not undergone relevant and appropriate training to enable them acquire technical skills for the job (Table 2).

Also, approximately half of the operators earn between R3 000 and R4 000/month, and less than 9\% earn over R5 000/ month. In the wake of inflation, a salary range of between R1 000 and R2 000 for a staff member with over 10 years of working experience on the same job may not be adequate. Further salary increases are contingent on additional education attainments but this is apparently unattainable because job entry qualifications were rudimentary and current schemes for upward educational mobility or in-service capacitation are either nonexistent or not implemented in some of the small water treatment plants visited across the province. This creates a situation of frustration and burnout due to lack of relevant education, training, skills development and performance of routine duties over years and poor incentives.

\section{Physicochemical water quality data}

The physicochemical qualities of the water samples are summarised in Table 3. Generally, temperature was within recommended limits for no risk (SABS class 0 standards) except for two plants at OR Tambo municipality (Umzimvubu and Bulolo), and one at Chris Hani Municipality (All Saints) where tempera- 


\begin{tabular}{|c|c|c|c|c|c|c|c|c|c|c|c|c|}
\hline \multicolumn{13}{|c|}{$\begin{array}{l}\text { TABLE } 2 \\
\begin{array}{l}\text { A summary of the physicochemical qualities of the water samples from the water treatment plants located in } \\
\text { the five district municipalities. RW (raw water); POT (point of treatment); POU (point of use) }\end{array}\end{array}$} \\
\hline \multirow[t]{2}{*}{ Municipality } & \multicolumn{3}{|c|}{ Turbidity (NTU) } & \multicolumn{3}{|c|}{ Conductivity (mS/m) } & \multicolumn{3}{|c|}{$\mathrm{pH}$} & \multicolumn{3}{|c|}{ Temperature $\left({ }^{\circ} \mathrm{C}\right)$} \\
\hline & RW & POT & POU & RW & POT & POU & RW & POT & POU & RW & POT & POU \\
\hline Cacadu & $\begin{array}{c}0.46- \\
79.1\end{array}$ & $\begin{array}{c}0.2- \\
16.61\end{array}$ & $\begin{array}{l}0.2- \\
7.97\end{array}$ & $\begin{array}{c}0.002- \\
94.0\end{array}$ & $\begin{array}{c}0.002- \\
96.4\end{array}$ & $\begin{array}{c}0.001- \\
96.6\end{array}$ & $\begin{array}{c}5.20- \\
9.58\end{array}$ & $\begin{array}{l}6.72- \\
11.25\end{array}$ & $\begin{array}{l}7.3- \\
9.95\end{array}$ & $\begin{array}{l}9.9- \\
21.3\end{array}$ & $\begin{array}{l}12.2- \\
22.7\end{array}$ & $\begin{array}{l}11.0- \\
22.8\end{array}$ \\
\hline Amatole & $\begin{array}{c}4.96- \\
32.7 \\
\end{array}$ & $\begin{array}{l}0.67- \\
8.92 \\
\end{array}$ & $\begin{array}{c}0.79- \\
16.3 \\
\end{array}$ & $\begin{array}{c}0.008- \\
20.3 \\
\end{array}$ & $\begin{array}{c}0.009- \\
39.1 \\
\end{array}$ & $\begin{array}{c}0.009- \\
63.1 \\
\end{array}$ & $\begin{array}{l}7.01- \\
9.58 \\
\end{array}$ & $\begin{array}{c}6.53- \\
8.9 \\
\end{array}$ & $\begin{array}{l}6.85- \\
8.64 \\
\end{array}$ & $\begin{array}{l}14.0- \\
24.3 \\
\end{array}$ & $\begin{array}{l}13.3- \\
22.7 \\
\end{array}$ & $\begin{array}{l}14.8- \\
22.4 \\
\end{array}$ \\
\hline Chris Hani & $\begin{array}{c}12.8- \\
335\end{array}$ & $\begin{array}{c}0.3- \\
4.3\end{array}$ & $\begin{array}{c}0.76- \\
4.43 \\
\end{array}$ & $\begin{array}{c}0.002- \\
41\end{array}$ & $\begin{array}{c}0.0034- \\
41.2\end{array}$ & $\begin{array}{c}0.0037- \\
43.1\end{array}$ & $\begin{array}{l}6.31- \\
8.95\end{array}$ & $\begin{array}{c}6.91- \\
8.6\end{array}$ & $\begin{array}{l}7.07- \\
9.75\end{array}$ & $\begin{array}{l}12.9- \\
27.7\end{array}$ & $\begin{array}{l}13.5- \\
22.6\end{array}$ & $\begin{array}{l}11.9- \\
22.93\end{array}$ \\
\hline Ukhahlamba & $\begin{array}{c}5.67- \\
115 \\
\end{array}$ & $\begin{array}{l}2.08- \\
22.0 \\
\end{array}$ & $\begin{array}{l}2.01- \\
22.9 \\
\end{array}$ & $\begin{array}{c}0.004- \\
16.9\end{array}$ & $\begin{array}{c}0.0036- \\
26.6\end{array}$ & $\begin{array}{c}0.003- \\
24.2\end{array}$ & $\begin{array}{l}6.18- \\
8.29 \\
\end{array}$ & $\begin{array}{l}4.68- \\
8.37 \\
\end{array}$ & $\begin{array}{c}4.8- \\
8.5 \\
\end{array}$ & $\begin{array}{r}13.1- \\
22.42 \\
\end{array}$ & $\begin{array}{l}12.5- \\
21.42 \\
\end{array}$ & $\begin{array}{r}14.1- \\
22.62 \\
\end{array}$ \\
\hline OR Tambo & $\begin{array}{c}5.79- \\
269 \\
\end{array}$ & $\begin{array}{l}0.31- \\
52.8\end{array}$ & $\begin{array}{l}0.36- \\
25.7\end{array}$ & $\begin{array}{c}0.087- \\
184.5\end{array}$ & $\begin{array}{c}0.091- \\
173.3\end{array}$ & $\begin{array}{c}0.09- \\
45\end{array}$ & $\begin{array}{c}6.93- \\
8.11\end{array}$ & $\begin{array}{l}7.09- \\
8.61\end{array}$ & $\begin{array}{l}7.13- \\
8.12\end{array}$ & $\begin{array}{l}16.3- \\
27.52 \\
\end{array}$ & $\begin{array}{l}15.8- \\
24.16 \\
\end{array}$ & $\begin{array}{l}16.1- \\
25.72 \\
\end{array}$ \\
\hline
\end{tabular}

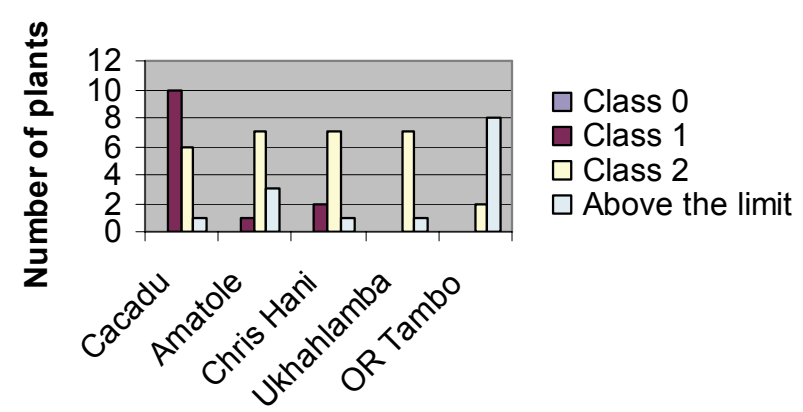

District Municipality

Figure 1

Turbidity standard compliance profile of the water treatment plants. Class 0: $<0.1$ NTU, Class 1: 0.1-1NTU, Class 2: >1-10NTU (SABS-241)

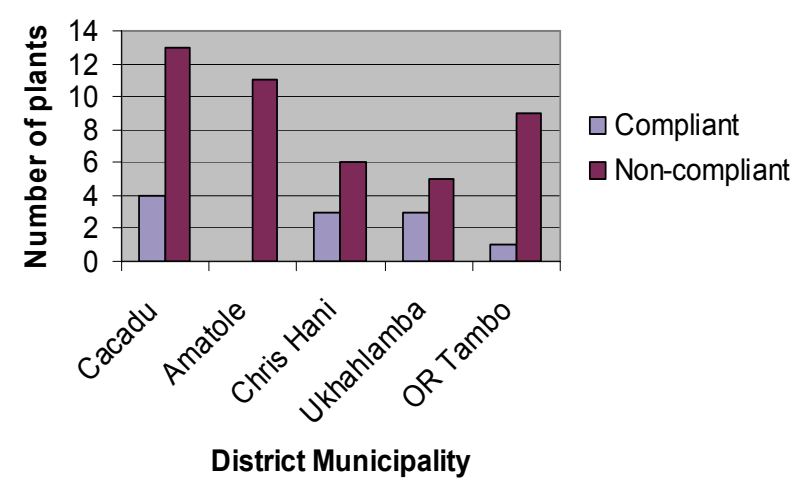

Figure 2

Total coliform standard compliance profile of the water treatment plants

ture over $25^{\circ} \mathrm{C}$ where observed. Temperature has a marked influence on the chemical and biochemical reactions that occur in water bodies. High temperature for instance, increases the toxicity of many substances such as heavy metals and pesticides. It also increases the sensitivity of living organisms to toxic substances (Dojlido and Best, 1993).

Conductivities of the treated water at the plants and at the points of end users were generally within the recommended limits for all the sites except for Somerset East, Cookhouse and Pearston plants in Cacadu Municipality which had a conductivity of 76.9, 96.6 and 172.6 respectively at the point of end users.
Also, turbidity values for treated water for the five districts fall within Class 2 level (Fig. 1), but in Cacadu, Amatole and Chris Hani District Municipality some of the plants fall within Class 1 level. Fifty five percent of the plants were within the acceptable SABS limits while the other $45 \%$ showed high turbidity values. Turbidity is caused by the presence of suspended matter, which usually consists of a mixture of inorganic matter, such as clay and soil particles, and organic matter. The latter can include both living matter (such as micro-organisms) and non-living matter (Momba and Binda, 2002). The variety of sources, character and size of suspended solids means that the measurement of turbidity gives only an indication of the extent of pollution. High turbidity therefore indicates the presence of organic suspended material, which promotes the growth of micro-organisms.

\section{Microbiological quality and chlorine residual profile}

The total coliform and faecal coliform densities of the treated water samples from the plants and the distribution systems revealed that most of the plants fell short of the compliance standards recommended by SABS-241 (9) and DWAF(10). Only $49 \%$ and $30 \%$ of the plants produced drinking water that complied with the South African recommended limits in terms of total and faecal coliforms at the point of treatment, respectively. Although some plants had low coliform numbers at the point of treatment, bacterial re-growth occurred in the distribution system thereby compromising the quality of the drinking water at the point of use. Consequently, only $28 \%$ of the plants fell within the recommended limits in terms of both total and faecal coliforms at the point of use. The total coliform counts were up to $240 \mathrm{cfu} / 100 \mathrm{~m} \ell$ at the point of treatment and up to $223 \mathrm{cfu} / 100 \mathrm{~m} \ell$ at the point of use while the faecal coliform counts were up to $25 \mathrm{cfu} / 100 \mathrm{~m} \ell$ and up to $98 \mathrm{cfu} /$ $100 \mathrm{~m} \ell$ at the point of treatment and at the point of use respectively. Cacadu district Municipality had the highest number of non-compliant plants followed by Amatole, OR Tambo, Chris Hani and Ukhahlamba District Municipalities in terms of total coliforms (Fig. 2).

Chlorine residuals of between 0.07 and 3.16 and between 0.01 and 1.51 were observed at the point of treatment and in the distribution system, respectively, in all the plants (Table 4). No chlorine residual was observed in the water collected from Dordrecht Water Treatment Plant in the Chris Hani District Municipality. Negative correlations were recorded between chlorine and the total and faecal coliform counts. 
This means that an increase in the amount of free chlorine residual resulted in a decrease in the numbers of total and faecal coliforms with respective correlations of -0.3595 and -0.2271 . While these correlations were not very high, they were statistically significant with p-values less than 0.05 . It is also important to note that coliform counts depended significantly on the concentration of free chlorine in the water. Specifically, an increase of $1 \mathrm{mg} / \ell$ in free chlorine resulted in a decrease of about 0.36 and 0.18 in the mean total coliform and faecal coliform counts respectively. In contrary, if no free chlorine was observed in treated drinking water, the mean total and faecal coliform counts would be expected to be 1.52 and 0.69 respectively. Previous studies have shown that the presence of disinfectant is crucial to water distribution security, providing a front-line defence against microbial contamination WRC (1993); Grabow (1996). Interestingly, however, bacterial counts were still high even in most plants with recommended residual chlorine.

To test the effect of various municipalities, sampling points and their interaction on amounts of chlorine used in drinking water treatment plants, an ANOVA was used. According to this analysis there was a significant effect of the predictors on the amount of chlorine in this province with model $\mathrm{F}=2.01$ and $p<0.048$. As to coliform counts, ANOVA revealed no statistically significant difference. This means that the variables in the model do not have significant combined effect on coliform counts. In fact, these variables together explain only $17.3 \%$ of the variability in total coliform counts only. When considering the individual effects, total coliform counts depended on municipality with $F=3.28$ and $p=0.0151$. Figure 4 summarises the interaction between the concentrations of chlorine residual and total and faecal coliforms in various district municipalities.

\section{Identification of bacteria isolates}

A total of 26 bacterial species and potential opportunistic human pathogens belonging to thirteen genera were variously identified in all the samples (Table 5). OR Tambo Municipality had a full compliment of all isolates identified, while 20 species were identified in Amatole and Ukhahlamba Municipalities, and in Cacadu and Chris Hani 14 and 19 species were identified respectively. Most of these isolates are enteric bacteria, and are the causative agents of infectious water-related diseases, which are the major cause of morbidity and mortality worldwide.
A common denominator to the poor water quality results observed above is the lack of regular assessment/management of water quality, including source protection, optimisation of water treatment, monitoring and maintenance. In this study we discovered that most of the systems that are managed by local municipalities encountered lots of problems including lack of understanding of legislative requirements, water quality standards/guidelines, requirements for effective monitoring, service delivery to smaller towns/communities is not as effective and efficient as that in the larger towns of the same local municipality, lack of communication between plant managers and operators, operators in some cases seem to be more knowledgeable than the supervisors, operators' level of education was very low and operators' wages also caused problems.

\begin{tabular}{|l|c|c|}
\hline \multicolumn{3}{|c|}{$\begin{array}{c}\text { TABLE 4 } \\
\text { Residual chlorine regimes of the treated } \\
\text { water (POU: Point of use) }\end{array}$} \\
\hline $\begin{array}{l}\text { District unici- } \\
\text { pality }\end{array}$ & $\begin{array}{c}\text { Chlorine residual (mg/e) } \\
\text { Plant reservoir }\end{array}$ \\
\hline Cacadu & $0.07-1.78$ & $0.01-0.54$ \\
\hline Amatole & $0.03-1.78$ & $0.04-0.59$ \\
\hline Chris Hani & $0.0-1.50$ & $0.00-0.53$ \\
\hline Ukhahlamba & $0.30-2.98$ & $0.05-1.51$ \\
\hline OR Tambo & $0.08-3.16$ & $0.02-0.80$ \\
\hline
\end{tabular}

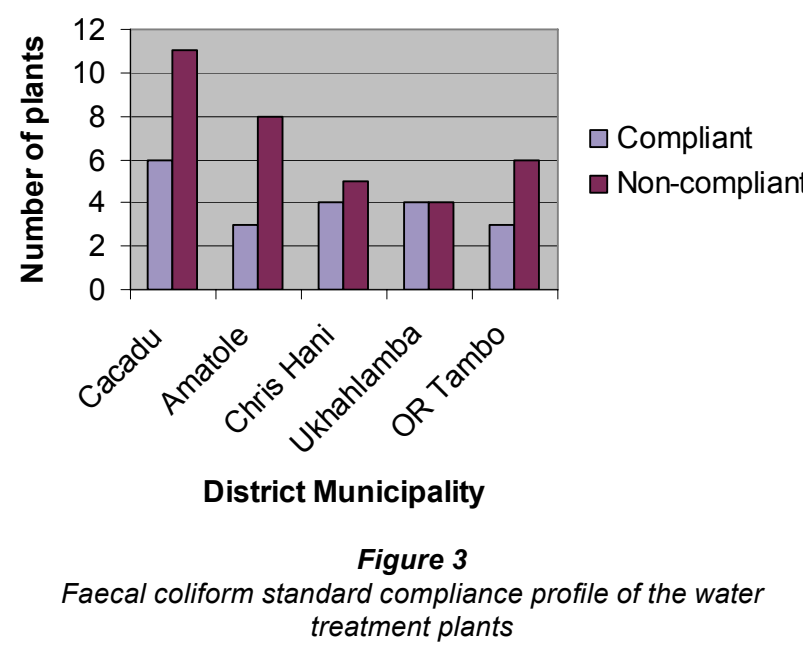

Figure 4

Plot of means of total (TC), faecal coliform (FC) and chlorine residual in five district municipalities, (CR chlorine residual)

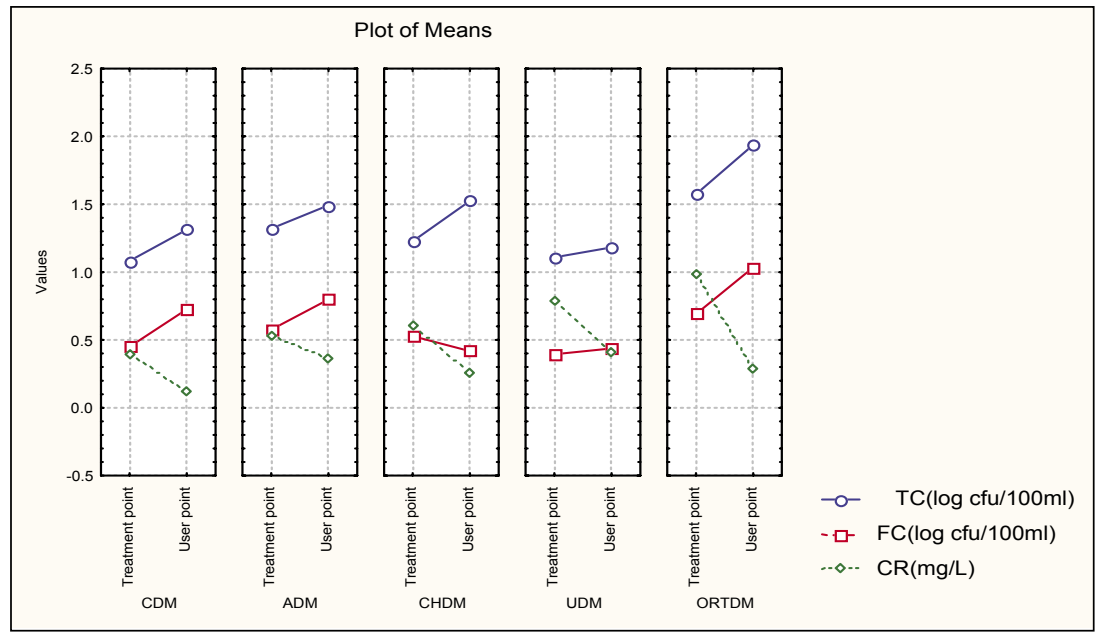




\begin{tabular}{|c|c|c|c|c|c|}
\hline \multicolumn{6}{|c|}{$\begin{array}{c}\text { TABLE } 5 \\
\begin{array}{c}\text { Profile of bacterial isolates identified from the water samples from the different } \\
\text { district municipalities water treatment plants }\end{array}\end{array}$} \\
\hline \multicolumn{6}{|c|}{ Bacterial isolates identified } \\
\hline Bacterial Isolates & Cacadu & Amatole & Chris Hani & $\begin{array}{l}\text { Ukhahl- } \\
\text { amba }\end{array}$ & OR Tambo \\
\hline Aeromonas hydrophilla & $\sqrt{ }$ & $\sqrt{ }$ & $\sqrt{ }$ & $\sqrt{ }$ & $\sqrt{ }$ \\
\hline Chryseomonas luteola & & & & & $\sqrt{ }$ \\
\hline Citrobacter braakii & & $\sqrt{ }$ & $\sqrt{ }$ & $\sqrt{ }$ & $\sqrt{ }$ \\
\hline Citrobacter freundii & & & & & $\sqrt{ }$ \\
\hline Enterobacter aerugenes & $\sqrt{ }$ & $\sqrt{ }$ & $\sqrt{ }$ & $\sqrt{ }$ & $\sqrt{ }$ \\
\hline Enterobacter cloacae & $\sqrt{ }$ & $\sqrt{ }$ & $\sqrt{ }$ & $\sqrt{ }$ & $\sqrt{ }$ \\
\hline Enterobacter gervoviae & & & & & $\sqrt{ }$ \\
\hline Enterobacter sakazakii & $\sqrt{ }$ & $\sqrt{ }$ & $\sqrt{ }$ & $\sqrt{ }$ & $\sqrt{ }$ \\
\hline Erwinia spp & & & & & $\sqrt{ }$ \\
\hline Escherichia coli & $\sqrt{ }$ & $\sqrt{ }$ & $\sqrt{ }$ & $\sqrt{ }$ & $\sqrt{ }$ \\
\hline Klebsiella ornitiolytica & $\sqrt{ }$ & $\sqrt{ }$ & $\sqrt{ }$ & $\sqrt{ }$ & $\sqrt{ }$ \\
\hline Klebsiella oxytoca & & $\sqrt{ }$ & $\sqrt{ }$ & $\sqrt{ }$ & $\sqrt{ }$ \\
\hline Klebsiella pantiola & & $\sqrt{ }$ & $\sqrt{ }$ & $\sqrt{ }$ & $\sqrt{ }$ \\
\hline Klebsiella pneumonia & & $\sqrt{ }$ & $\sqrt{ }$ & $\sqrt{ }$ & $\sqrt{ }$ \\
\hline Klebsiella terrigena & & & & & $\sqrt{ }$ \\
\hline Pantoea spp & & $\sqrt{ }$ & & & $\sqrt{ }$ \\
\hline Photobacter damsela & & & & $\sqrt{ }$ & $\sqrt{ }$ \\
\hline Pseudomonas aeruginosa & $\sqrt{ }$ & $\sqrt{ }$ & $\sqrt{ }$ & $\sqrt{ }$ & $\sqrt{ }$ \\
\hline Pseudomonas flourescens & $\sqrt{ }$ & $\sqrt{ }$ & $\sqrt{ }$ & $\sqrt{ }$ & $\sqrt{ }$ \\
\hline Pseudomonas putida & $\sqrt{ }$ & $\sqrt{ }$ & $\sqrt{ }$ & $\sqrt{ }$ & $\sqrt{ }$ \\
\hline Salmonella arizonae & $\sqrt{ }$ & $\sqrt{ }$ & $\sqrt{ }$ & $\sqrt{ }$ & $\sqrt{ }$ \\
\hline Salmonella spp & $\sqrt{ }$ & $\sqrt{ }$ & $\sqrt{ }$ & $\sqrt{ }$ & $\sqrt{ }$ \\
\hline Serratia odorifera & $\sqrt{ }$ & $\sqrt{ }$ & $\sqrt{ }$ & $\sqrt{ }$ & $\sqrt{ }$ \\
\hline Serratia liquefaciens & $\sqrt{ }$ & $\sqrt{ }$ & $\sqrt{ }$ & $\sqrt{ }$ & $\sqrt{ }$ \\
\hline Serratia marcescens & $\sqrt{ }$ & $\sqrt{ }$ & $\sqrt{ }$ & $\sqrt{ }$ & $\sqrt{ }$ \\
\hline Vibrio fluvialis & & $\sqrt{ }$ & $\sqrt{ }$ & $\sqrt{ }$ & $\sqrt{ }$ \\
\hline TOTAL & 14 & 20 & 19 & 20 & 26 \\
\hline
\end{tabular}

\section{Conclusion}

The provision of sustainable water to communities is presently a top priority of the South African constitution. However, in rural areas where water supply existed, drinking water quality is often poor and could not be considered safe. Although, chlorination in various forms is regarded as a reliable, cost-effective method for disinfecting water for drinking purposes, however, the application of chlorine present problems, especially in the above mentioned areas that we visited where the lack of sufficient expertise on dosing of chlorine was experienced. This study provides information on the failure of small water treatment plants in the Eastern Cape Province of South Africa to provide safe drinking water. To ensure sustainability of these systems, the important requirement is to ensure that the system is reliable; operators are well trained; communities are involved in the decision making; back-up systems are available; and that financial management is also well recognised.

\section{References}

BEYL N AND ASSOCIATES (2003/2004) Courtesy of Focus on Buffalo City. Infobiz.

CSS (1998) Statistics in Brief. Central Statistical Services, Pretoria.

DOJLIDO JR and BEST GA (1993) Chemistry of Water and Water Pollution. Ellis Horwood Ltd, Great Britain.

DWAF (DEPARTMENT OF WATER AFFAIRS AND FORESTRY) (1996) South African Water Quality Guidelines for Domestic Use ( $2^{\text {nd }}$ edn.) Pretoria, RSA.
GRABOW WOK (1996) Waterborne diseases: Update on water quality assessment and control. Water SA 22 193-202.

KASRILS R (2004) A Decade of Delivery. Minister of Water Affairs and Forestry.

LLOYD BJ and BARTRAMS JK (1991) Survellance solutions to microbiological problems in water quality control in developing countries. Water Sci. Technol. 24 (2) 61-75.

MACKINTOSH G and COLVIN (2002) Failure of rural schemes in South Africa to provide potable water. Environ. Geol. 1-9.

MEY J (1998) Poverty and Inequality in South Africa. Report prepared for the Office of the Executive Deputy President and Inter Ministerial Committee for Poverty and Inequality, Durban.

MOMBA MNB and BINDA MA (2002) Combining chlorination and chloramination processes for the inhibition of biofilm formation in drinking surface water system models. J. of Appl. Microbiol. 92 641-648.

MOMBA MNB, NDALISO S, BINDA MA and MAKALA N (2002) Inhibition of Biofilm Regrowth in Potable Water Systems. WRC Report No 1023/1/02. Water Research Commission, Pretoria, RSA.

MOMBA MNB, TYAFA Z and MAKALA N (2003) Rural water treatment plants fail to provide potable water to their consumers: Alice water treatment plant in the Eastern Cape Province of South Africa. S. Afr. J. Sci. 100 307-310.

SABS (SOUTH AFRICAN BUREAU OF STANDARDS) (2001) SABS 241-2001: Specification for Drinking Water. Pretoria, South Africa.

SWARTZ CD (2000) Guidelines for the Upgrading of Existing Small Water Treatment Plants. WRC Report No. 730/1/100.

WHO (2003) Emerging Issues in Water and Infectious Disease, World Health Organisation, Geneva, Switzerland.

WRC (WATER RESEARCH COMMISSION) (1993) Guidelines on the Cost Effectiveness of Rural Water Supply and Sanitation Projects. WRC Report No. 231/1/93. Water Research Commission, Pretoria, South Africa. 